\title{
Teacher Professional Development in Education 4.0: Awareness of Digital Literacy
}

\author{
Rosanita Tritias Utami ${ }^{1}$, Nia Roistika ${ }^{1}$, Umdatul Khoirot ${ }^{1}$, Moh Hanafi ${ }^{1}$, Dwi Ima Hermin- \\ ingsih ${ }^{2}$ \\ \{rosa.utami@stkippgritulungagung.ac.id\}
}

STKIP PGRI Tulungagung, Indonesia ${ }^{1}$, Universitas Tulungagung, Indonesia ${ }^{2}$

\begin{abstract}
The Revolution of Industry 4.0 (IR 4.0) brings a new stimulus to educational system in Indonesia and causes education transformation. Technology used in education field is a segment of education 4.0 that can train students to improve their learning achievement. The process of teaching learning to achieve this goal is started from the teachers' awareness of digital literacy. Lecturers as teachers or educator in higher education play a crucial role in their students' lives. Unfortunately, the motivation of lecturers to participate in teacher professional development program is still low. In fact, participating in the program support their professional development process. This study aims to explore how teachers' awareness of digital literacy support their work in conducting three principles of higher education teachers. This exploration was determined from literature review and analysis of policy documents. The finding shows that digital literacy and teachers' professional development in education 4.0 impact the teachers to have their professional jobs well done. Digital literacy can be implemented into numerous aspects. It is very practical and gives benefit for teachers as a professional lecturer to do Indonesia's three principles of higher education. Indonesian government must support developing good quality teachers since good education is the most crucial tool to solve various problems. Teachers as lifelong learners must maintain their professional development (PD) to face challenges in education 4.0.
\end{abstract}

Keywords: Teachers Professional Development, Digital Literacy

\section{Introduction}

Industrial Revolution 4.0 (IR 4.0) brings a new stimulus to educational system in whole world, including in Indonesia and causes big leap or education transformation. Using technology in teaching learning is a part of education 4.0. There have been some researches, experimental, action or even conceptual research, conducted by some experts related to the use of technological innovations, known as Information and Communication Technology (abbreviated into ICT) on education, includes in English language teaching. Education 4.0 can train students to produce innovation and the process of teaching learning to achieve this goal is started from the teachers. Teachers in higher education, as known as lecturers, play a crucial role in their students' lives.

For the students, teachers are often chosen as their first significant role model and it can influence the teaching learning materials that students learn at campus as well as influence the students' beliefs and attitudes in their lives. 
Education is the most crucial tool to solve differing problems and this is the reason why government should develop teachers' quality. Teachers as lifelong learners must maintain their professional development (PD) to face challenges in education 4.0. The Indonesia government through the ministry of education stated that Indonesia should be ready to face globalization in education related to IR 4.0.[1]

Globalization here means a process where the countries around the world will be more connected each other as a result of massive trade and intercultural exchange. The minister of education in Indonesia, Muhammad Nasir, stated that there are three main elements why Indonesia government must be innovative in developing its educational system related to IR 4.0; education globalization, strategies, and organization and its structure which covers creativity, innovation, multidiscipline, entrepreneur, etc.

Based on the background explanation, it is clear that teachers have more important role as well as the use of ICT in education in facing IR 4.0. The problem will be discussed now is how to develop teachers professional development in education 4.0.

\section{Literature Review}

\subsection{Teacher Professional Development}

Teacher professional development covers skills, knowledge and on-going learning opportunities they have to improve their ability in order to have their professional works well done. Hansen-Thomas, Casey, and Grosso [2] stated that "teachers learn most when they are actively engaged in examination of their regular practice (i.e., teaching and learning) and how the professional development activities contribute to their daily work". Through professional development, teachers will be able to gain more knowledge.

This professional development must be achieved by teachers and it can be gained by having training, workshop, course, etc. Unfortunately, this training is only given in a short and limited period of time and as the result, it gives only little effect on the improvement of teachers' professional development. For example, teachers are often willing to join training only to have certificate in order to get job promotion.

This lack of motivation become common problem as well as financial or funding problem as Yuwono and Harbon [3] found that it is common for teachers to have another work as the result of their financial issue. This issue affected them in participating professional development training or workshop because of their limited time, money and energy to do so.

Teachers should be aware that professional development is very important in growing their professional development. There are some universities provide professional programs for the teachers/lecturers for example by conducting basic skills development program as known as PEKERTI1 with professional instructors from universities coordinator (LLDIKTI) Besides joining PEKERTI, attending conferences is the most common activity of professional development program that higher education teachers do.

It means that there are a lot of forms of teacher professional development that teachers can join such as presenting a paper or attending a conference or workshop, reading scholarly academic articles, keeping a teaching journal, and engaging in online professional development as stated by Murray [4]. It cannot be denied that there may be still many English teachers who

${ }^{1}$ PEKERTI is a training program for Indonesia higher education teachers to develop their basic instructional skills held by ministry of higher education 
do not take part in professional development because they do not have adequate and well information about the programs. Another problem is teachers often spend too many hours teaching in the classroom and they are too busy with other administration or documentation things.

\subsection{Reasons why a higher education teacher should participate in professional development}

According to Wong [5], there are some reasons why a higher education teacher should engage in professional development:

a. To find out the strong and weak points a teacher has. When teachers are not able to find out their strengths as educators, they will not be able to get chance to develop their professionalism based on their strength and it will not give any benefit for them especially to have greater impact of self-development. A teacher who does not know their weakness will fail to find out what to change or improve because he does not know what the problems he has

b. To get new knowledge. Getting new knowledge is very important for a teacher in the effort of raising his professional development. Getting more knowledge means having more idea and creativity in teaching or delivering materials to the students. It is, indeed, able to support a teacher to create new atmosphere in teaching learning activity.

c. To find solution of teacher's particular problem. Being a teacher means having communication and interaction with students and colleagues. Sometimes a teacher meets problem in relation of teaching and learning activities. It could be problem of ineffective teaching method, students' difficulties in receiving the materials given by the teacher, etc. joining professional development seminar or training can help teacher to find out the solution of the problem since in the training or seminar, he meets other teachers and experts so he can discuss about the problem.

d. To improve skills based on society or field demands. The need of society in relation of education system changes over time. It means that a teacher should aware the changes and should adapt with the situation. Upgrading skill due to the changes is very important so he will keep his knowledge and skill updated.

\subsection{Digital Literacy}

Definition of literacy according to UNESCO is the ability to identify, understand, interpret, create, communicate and compute, using printed and written materials associated with varying contexts. According to Luis [6], a continuum of learning in literacy supports people to attain their goals, to develop their knowledge and potential in order to participate fully in larger society.

Digital literacy is an important issue to support development of digital competencies as well as teachers' professional competence in order to develop their knowledge level.

\section{Method}

Review of literature and analysis of policy document was applied to construct a conceptual study of this paper related to higher education teacher professional development in education 4.0 which was focused on their awareness of digital literacy and its role in supporting tridharma 
perguruan tinggi2. The literature in this study was selected from the article of acknowledged journals. In addition, the Indonesian policy documents related to tridharma perguruan tinggi was derived from higher education ministry policy document that was thematically analyzed to examine how digital higher education teacher awareness support the implementation of tridharma.

\section{Finding and Discussion}

\subsection{Digital Literacy and Higher Education Teachers' Professional Development in Indonesia}

The relationship between digital literacy and teachers' professional development in education 4.0 can be seen clearly; it supports the teachers to have their professional jobs well done. Digital literacy can be implemented into various aspects. It can very useful and give benefit for teachers as a professional lecturer to do Indonesia's three principles of higher education (as known as tri dharma perguruan tinggi); comprising education and teaching, research and community services as stated in Republic of Indonesia Law number 12 about Higher Education [7].

a. First principle: education and teaching

Being professional in education and teaching is first principle a higher education teacher has to do. Digital literacy can support teacher to achieve professional in education and teaching. The changes of teaching learning method from teacher-centered to students-centered make the role of teacher become facilitator. Teacher should be able to make students active in class, including finding information to support them in understanding the materials they are discussing in the classroom. Internet is one media for students to get more information they need. Here, the role of teacher is to support the students and to ensure that they use the media correctly and get the needed information. Teacher's digital literacy will be useful to deliver the materials and to create new atmosphere of teaching and learning activity.

In relation to education 4.0, teacher's digital literacy will be very useful when teacher would like to conduct online learning. Without digital literacy, a teacher will not be able to conduct online learning smoothly since it demands the teacher to digital literate.

b. Second principle: research

As a professional lecturer, conducting scientific research is a must as part of three principles of higher education. Teachers are demanded to publish their article in reputable scientific journal. Writing a scientific article needs teacher's understanding about submission guidelines since each journal has different guidelines, terms and conditions. Digital literacy has very important role to help teacher to achieve the goal. It is very helpful to use reference manager application such as Mendeley or Zotero in order to write scientific article. This application can support teachers as writer to do citation on their papers. Using these application can also help teachers to avoid plagiarism.

c. Third principle: community service

The third principle a higher education teacher should do as a professional teacher is community service. In this activity, teacher can give contribution to their community or society. Digital literacy can support teacher to do this principle, for example if teachers would like to give training to English Teacher Community as known as MGMP (Musyawarah Guru Mata Pelajaran in level of junior and senior high school) in relation to digital literacy, especially in using ICT as media to teach English as foreign language. In this case, higher education teachers' role is as training committee who manage the training activity or as note speaker who gives the material to the English teacher.

2 Tridharma Perguruan Tinggi is three principles of higher education that must be conducted by every Indonesian higher education teacher. 


\subsection{What should teachers do to keep training their professional development in relation to education 4.0?}

There are various ways for higher education teachers to keep raising their professional development, and one of them is by joining community or organization. Joining organization which focuses on teacher professional development is very important for a teacher. In Indonesia, there are some organizations that concern teacher professional development. In English language teaching, there is an organization namely TEFLIN (The Association for the Teaching of English as A Foreign Language in Indonesia). This organization gives its outstanding concern on English teacher professional development. TEFLIN often holds workshop for English teacher on order to support them in raising their skills and having new knowledge. One of the workshop was held in 2016 and it was organized by TEFLIN in Central Java.[8]. The latest workshop held by TEFLIN in Central Java was on January 16, 2019. The materials given in the workshop was very outstanding and support teachers to raise their professional development, especially in facing education 4.0 in which teachers should have awareness of digital literacy. Some workshop programs held by TEFLIN were supported by RELO (Regional English Language Office) in which it supports the mission of the Public Affairs Section of the United States Embassy to promote mutual understanding between Indonesians and Americans through its informational, educational and cultural programs. It indicates that TEFLIN has great concern in supporting English teachers in Indonesia to raise their professional development.

Besides holding workshop for teacher, TEFLIN holds annual conference as well. This conference gives opportunities for teacher to share their knowledge and experience with other English teachers and consulting with the experts. [9]

\section{Suggestions}

\subsection{Suggestion for higher education institution in relation to support teachers professional development in facing Education 4.0.}

Raising teacher professional development especially in relation to digital literacy is teachers' personal responsibility, however the role of institution where the teachers works also important. Support and motivation from institution gives positive contribution for the teachers. They will feel they are supported and motivated to keep raising their professional development. They will feel that the institution give big concerns for them. Funding support is a common issue faced by teachers, especially those who work in private university in suburb areas. Joining international conference is a big problem for some these teachers since it needs some fee to expense. Here, the institution can give financial support by selecting teachers who really have good achievement to join the conference. This policy is expected to be able to motivate teachers to have more achievement.

Besides giving financial support, institution can also hold workshop for their teachers to keep raising their professional development. The workshop materials can be related to the courses about data and digital or technological literacy. It is expected that through professional development, teachers will be able to develop their pedagogical knowledge as well as their professional knowledge. Being a teacher means being a researcher as well because a teacher can start his scientific research from his classroom practices by doing an action research.

\subsection{Suggestion for government}

Government has great role in supporting higher educational teachers to keep them raising their professional development. The steps the government has taken to support and motivate teachers

Government should provide opportunities for the teachers to raise their professional development. Raising teacher professional development means contributing the teacher quality and student learning improvement. The government, in this case the Ministry of Research, Technology and Directorate of Higher Education is expected to give more attention and concern to raise professional development for higher education teachers. The teachers' professional growth should be supported by the government not only as 
teachers/lecturers in the classroom but also as professionals in their field to contribute to community or society. Government should manage good plan to launch their policy or programs and find out what constitutes effective continuous the professional development. It is important to do because professional development needs good plan and coordination.

\section{References}

[1] kemenristekdikti, "Indonesia Siap Menyambut Globalisasi Pendidikan dan Revolusi Industri Ke-4,” 2018. [Online]. Available: https://ristekdikti.go.id/menristekdikti-nasirindonesia-siap-menyambut-globalisasi-pendidikan-dan-revolusi-industri-ke-4/. [Accessed: 04-Dec-2018].

[2] L. Hansen-Thomas, H., Casey, P. J., \& Grosso, "Multiplying the effect of professional development: Teachers training teachers.," TESOL J., vol. 41, no. 1, pp. 129-150, 2013.

[3] L. G.I., Yuwono, \& L. Harbon, "English Teacher Professionalism and Professional Development: Some Common Issues in Indonesia," Asian EFL J., vol. 12, no. 3, pp. 145$163,2010$.

[4] A. Murray, "Empowering teachers through professional development," English Teach. Forum, vol. 48, no. 1, pp. 2-11, 2010.

[5] M. S. Wong, "Fifty Ways to Develop Professionally: What Language Educators Need to Succeed," Lang. Educ. Asia, vol. 2, no. 1, pp. 142-155, 2011.

[6] L. Crouch, "Measuring Functional Literacy and Numeracy for Lifelong Learning," 2017. [Online]. Available: http://uis.unesco.org/en/blog/measuring-functional-literacy-andnumeracy-lifelong-learning. [Accessed: 04-May-2018].

[7] G. Indonesia, Undang-Undang Republik Indonesia Nomor 12 tahun 2012 tentang Pendidikan Tinggi. Indonesia, 2012.

[8] Admin, "TEFLIN Central Java holds Workshop for teachers," 2016. [Online]. Available: http://www.teflin.org/news/read/TEFLIN+Central+Java+holds+Workshop+for+teachers. [Accessed: 14-Dec-2018].

[9] S. Borg, "The Benefits of Attending Conferences.," ELT J., pp. 1-12, 2014. 